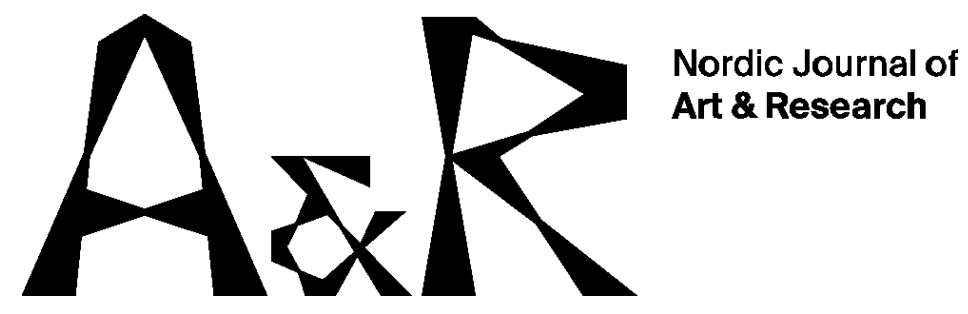

\title{
No Waste Cooking - An Exploration of Politics as Redistribution of the Sensible
}

\author{
Sissel Gunnerød ${ }^{1}$ \\ OsloMet - Oslo Metropolitan University
}

\begin{abstract}
Life in affluent, big city society with huge amounts of easily accessible food results in extensive food waste on different levels, causing greenhouse gas emissions. The aim of this article is to explore and discuss whether-and if so, how-an urban art action may contribute to displacement in social food practices. Using the Swedish artist Andrea Hvistendahl's ongoing project No Waste Cooking as a case study, I approach this art action through Jacques Rancière's concept of politics as distribution and redistribution of the sensible. The most important research questions are: How is No Waste Cooking involved in redistributing social food waste practices? How is the project related to similar projects in visual culture?
\end{abstract}

No Waste Cooking concerns saving and upgrading food from grocery stores that would otherwise be thrown away. As an urban gleaner, Hvistendahl gathers this food and intervenes between grocery stores and consumers, creating a space for leftovers, sensations and reflections. Food after its expiration date has become the fulcrum, the third thing, a common reference in which the artist, the visitors, as well as the readers are invited to reassess our values and behavior patterns on food, and elaborate and develop further discussion and proliferation. In this sense, No Waste Cooking has a didactic function, displaying ethical questions and possible ways to 
Sissel Gunnerød: No Waste Cooking - An Exploration of Politics as

Redistribution of the Sensible

deal with them without straightforward answers. Albeit in a modest alteration, art becomes life.

Keywords: art, politics, redistribution of the sensible, dissensus, food waste

\section{Introduction}

Life in affluent, big city society with huge amounts of easily accessible food results in extensive food waste on different levels, causing greenhouse gas emissions. Stuart (2009) claims that throughout the developed world, food is treated as a disposable commodity disconnected from the social and environmental impact of its production (p. xvi). Food is not just a commodity, however: according to Stuart (2009), we need to recognize that the world is negatively affected by our consumption and waste of food (p. xvii). It hurts both people and the planet.

The food chain accounts for up to $30 \%$ of greenhouse gas emissions (Stuart, 2009; Garnett, 2011). This includes all stages in the lifecycle of the food chain; the farming process, manufacturing, distribution, refrigeration, retailing, food preparation in the home, as well as waste disposal produce greenhouse gasses. This article focuses on food preparation in the home in particular.

Garnett (2011) claims that technology efficiency is not sufficient in mitigating food related to greenhouse gas emissions (pp. 28-29). ${ }^{2}$ She points out that a change in consumption and behavior is necessary. We must address how our food is produced and distributed, as well as what we eat. Greenhouse gas-intensive food types, such as meat and dairy, ought to be reduced (Garnett, 2011, p. 31).

From a growing body of research, we have knowledge about the connection between food and greenhouse gas emissions and advice on how to reduce them (Stuart, 2009; Garnett, 2011; Nicholson, 2014). Why, then, is it so difficult to change food consumption patterns? How do we implement changes in our everyday lives? To the

\footnotetext{
${ }^{2} \mathrm{~A}$ rebound effect might occur when technology is improved. Cold chain technology has caused a shift toward production and consumption of more refrigeration-dependent food, such as salads and berries. Refrigeration is a major source of emission (Garnett, 2011, pp. 28-29). Garnett (2011) states that waste and refrigeration are intertwined: technology has created a development based on the availability and ubiquity of products of high quality, which leads consumers to expect no less. The imperative of considerable choice can require more space, bigger refrigerators and lead to overpurchasing, which in turn generates more waste. As such, technology has had an important role in shaping our food habits and expectations.
} 
Sissel Gunnerød: No Waste Cooking - An Exploration of Politics as Redistribution of the Sensible

best of my knowledge, there is little research from the aesthetic field regarding this issue. According to Dessein, Soini, Faircloughs, and Horlings (2015), culture matters in sustainable development. With the aim of considering contemporary art in connection with general societal processes, I look to sensations and reflections from contemporary art based on food waste. How may artistic interventions offer counterperspectives to the prevailing practice of consuming food as a commodity in big cities?

This article explores and discusses whether-and if so, how-an ongoing urban art action, Swedish artist Andrea Hvistendahl's No Waste Cooking, may contribute to displacement or redistribution in social food practices . ${ }^{3}$ Using Hvistendahl's project as a case study, I approach this art action through the French philosopher Jacques Rancière's concept of politics as a distribution of the sensible (Rancière, 2009b, 2010). The most important research questions are: How is No Waste Cooking involved in redistributing social food waste practices? How is the project related to similar projects in visual culture?

In exploring these questions, I play a part as researcher, thinking with perspectives from theories and concepts of politics "on art," as an interpretative perspective is common in humanities and social sciences. However, I also play a part as a participant in thinking with art, as participation lies at the core of the artwork: No Waste Cooking is an invitation to which I respond with reflections.

\section{An Art Action}

The art action is about saving and upgrading food from grocery stores that would otherwise be thrown away. (Hvistendahl, 2011). The project's aim is "to create a debate and be part of changing the way we think about food and our lifestyle" (Hvistendahl, 2011). Hvistendahl wants to save food and the climate together with creating new energy and thoughts in the visitors.

The project started in 2009 right before the Climate Meeting in Copenhagen and was shown at the artist-run gallery Studio 44 in Stockholm as part of the group exhibition WIP, or "Work in Progress." In 2013, Hvistendahl repeated the action in collaboration with the artist Lotte Nilsson-Vällima as part of the group exhibition "Survival of the

\footnotetext{
${ }^{3}$ The artist refers to the project as an art action in her blog (Hvistendal, 2013). Thus, the focus is on the process of doing or acting. Hvistendahl takes action to change the prevailing practice of discarding food.
} 
Sissel Gunnerød: No Waste Cooking - An Exploration of Politics as Redistribution of the Sensible

Fittest" - Concerning Circumstances at Studio 44, which involved placing a provisional kitchen in the studio. For No Waste Cooking, Hvistendahl collaborates with grocery stores and gets food after its final date recommendations. The food is then prepared live in the gallery and served free of charge to the art visitors.

Conversation with the visitors is an important part of the artwork, as the artist hopes for a synergy effect on the visitors when they cook at home. She challenges the habit of wasting food based on final date recommendations in grocery stores. She faces the fear of eating old food that was developed by the food industry with the impact it has on the climate. The audience also gets the experience of tasting fresh, fully edible food in a tangible and sensuous way; in 2013, the chef also invited the audience to participate in cooking the food. Because Hvistendahl does not know in advance what she gets from the grocery store, improvising is part of the game, but she does prioritize vegetarian food with elements of meat and fish. However, she does not want to serve hot dogs to visitors and rather gives those away when she receives them so people can make their own dinner at home.

I visited Studio 44 in November 2013 and ate my dinner as part of No Waste Cooking. It was like a colorful and diverse tapas bar without the meat and shrimp, but nevertheless with salmon, blue mussels, fried bananas, onions and Swedish turnips, vegetarian casserole, vegetarian pie and salad. An apple pie, smoothies and many unknown fresh fruits from all over the world were served as dessert. The following day when I came back for lunch, a volunteer cook served roast pork with bread and salad together with heated vegetarian casserole, leftovers from the day before. Even in this project leftovers occur. Hvistendahl told me that she also used the freezer to store food, thus mitigating waste even further: No Waste Cooking is truly the art of eating up (Hvistendahl, 2013). 
Sissel Gunnerød: No Waste Cooking - An Exploration of Politics as Redistribution of the Sensible

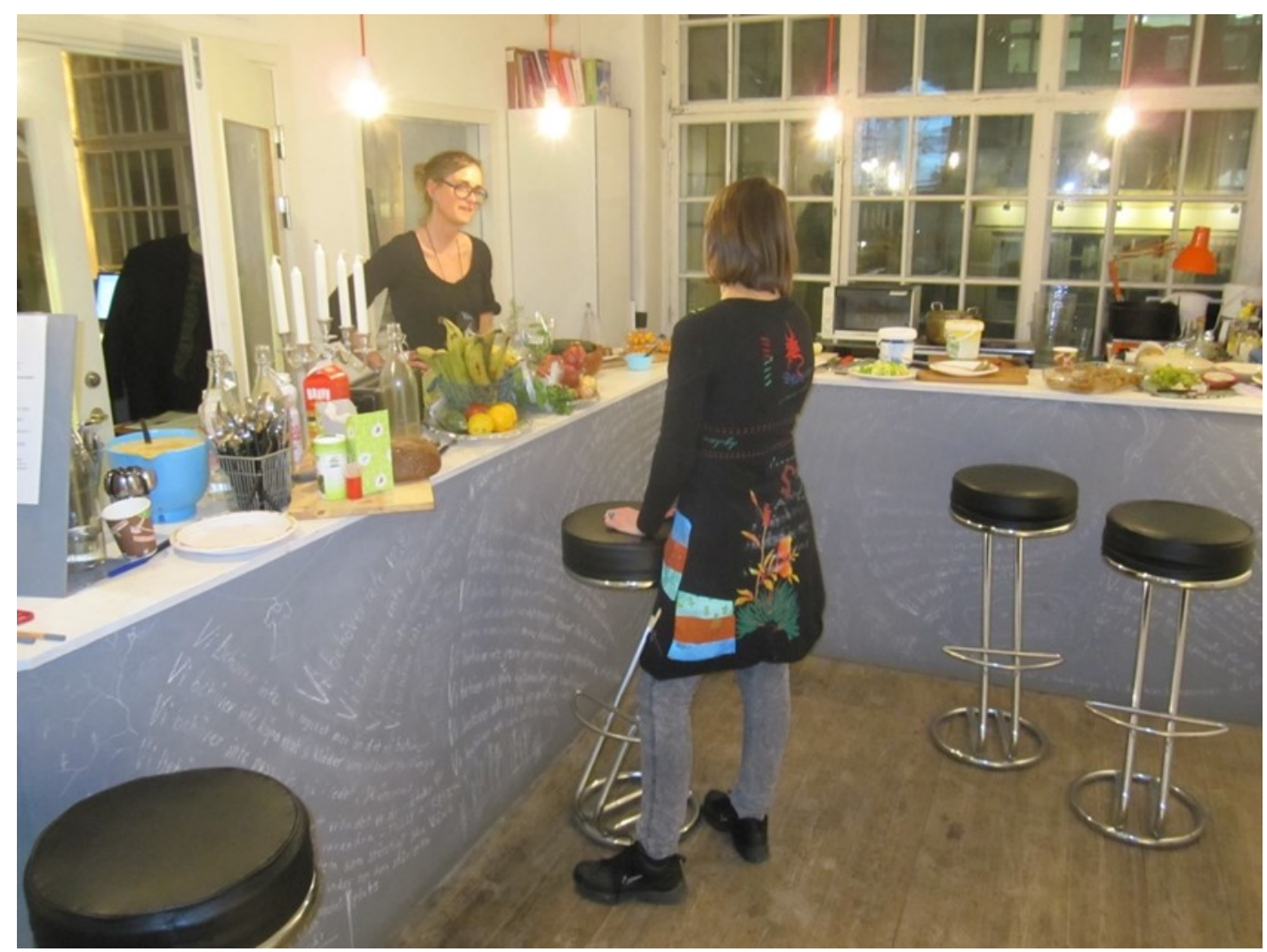

Figure 1. Andrea Hvistendahl, No Waste Cooking in Gallery Studio 44, Stockholm 2013. Photo: Geir Brunsvik
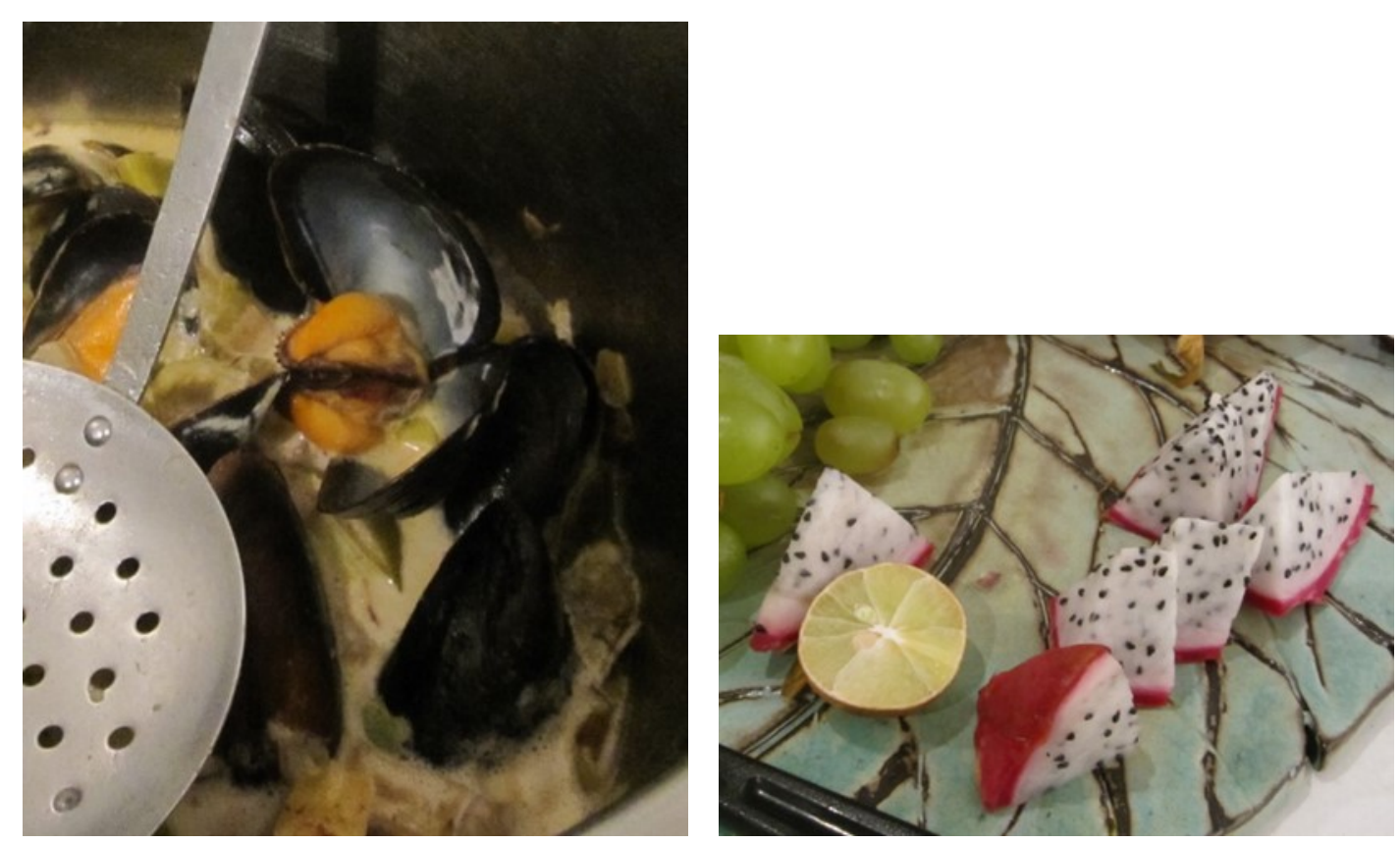

Figures 2 and 3. Andrea Hvistendahl, No Waste Cooking (2013) details. Photo: Sissel Gunnerød 
Sissel Gunnerød: No Waste Cooking - An Exploration of Politics as

Redistribution of the Sensible

\section{A Social and Relational Art Practice}

May Hvistendahl's art project be understood as a social and relational art practice? Bourriaud (2007) has described art practices in the nineties with the concept relational aesthetics. The importance of relational aesthetics is connected to the social function of art and its fluctuating and transitory character. While art in modernity should prepare or predict a future to come, art today models possible universes (Bourriaud, 2007, p. 15). Art functions as a social space (in-between) and a meeting condition (Bourriaud, 2007, pp. 17, 23). This kind of art practice establishes relations between the subjects. Every artwork becomes a suggestion of how to live in the world together, repeatedly generating new relations in the world (Bourriaud, 2007, p. 29). I think of how Hvistendahl particularly in No Waste Cooking 2013 was concerned about the communication situation during the meal, generating new reflections for the visitors, as well as their friends and family.

No Waste Cooking also leads us to the early seventies conceptual and artist-run restaurant Food in Soho, New York. Fresh seasonal food was prepared in open kitchens at a time when convenience food was on the rise. Vegetarian food was also on offer. The artist Gordon Matta-Clark largely designed and built Food and organized art events and performances there. He also commissioned artists to create meals. The restaurant was a social space for artists and art projects. Maybe Food in Soho is comparable to the Danish-Icelandic artist Olafur Eliasson's contemporary, well-reputed SOE Kitchen for the staff at his Berlin studio, which functions as a social glue, a place for ideas and fresh food to become healthy and fuel the whole machine of the studio. Working in the studio means working in little departments with teams and hierarchies, while the kitchen is a meeting place across these boundaries. The food is fresh, organic and vegetarian, frequently vegan and sourced mostly within a 10 -kilometer radius of Berlin. Staff can also take any leftovers home so nothing is wasted.

Even though Hvistendahl has prepared food in the artist-run Studio 44 twice, No Waste Cooking is not site-specific like Matta-Clark's was. She has also prepared food in Gothenburg (2014) and is willing to do No Waste Cooking in other locations and cities as well. ${ }^{4}$ She addresses the project to art visitors in general; so is the case with the invitation to the audience to participate in the cooking. In comparison, we might

\footnotetext{
${ }^{4}$ In Gothenburg, she made No Waste Cooking for students and staff at Chalmers University of Technology.
} 
Sissel Gunnerød: No Waste Cooking - An Exploration of Politics as

Redistribution of the Sensible

say that Hvistendahl's approach is much broader than Matta-Clark's in New York. I suggest that Food was more oriented toward art and social relations while No Waste Cooking is more concerned about changing the future. When I visited Studio 44, I talked more with the artist than the other visitors, but the focus was on the food and conversations on food and sustainability, not social relations; I discovered a critical agenda creating sensations and reflections, which I will come back to later. Considering Eliasson's SOE Kitchen and Hvistendahl's No Waste Cooking, there are parallels in their thinking. Both believe in the impact of physical and sensuous experiences on our life and thinking (Hvistendahl, 2013; Eliasson, 2016).

We are also reminded of Rirkrit Tiravanija, who in 1992 created the exhibition Untitled at 303 Gallery, New York. The gallery was converted into a kitchen, where he served rice and Thai curry for free. The visitors were invited to interact with contemporary art and each other in a more sociable way. The distance between the artist and viewer blurred. The viewer was not looking at the art, but was part of it when eating the rice and curry and talking with friends or new acquaintances (Rirkrit Tiravanija, 2012). According to Bourriaud (2007), Tiravanija and his artwork are the quintessence of relational aesthetics. The artwork is transitory and the meaning open, dependent on the viewer's participation.

When reading Tiravanija's dinner as an intertext to No Waste Cooking, the sociable aspect of No Waste Cooking seems more obvious. As in Tiravanija's piece, the visitor at No Waste Cooking is part of the artwork when eating the food. The visitor is invited to fill in, even substitute, the artist to do no waste cooking, a rare occasion to influence the artwork and communication situation. Visitors, including me, asked the cook about the meal and what it consisted of. In this way, the meal functions as a meeting point. ${ }^{5}$ However, Hvistendahl seems more preoccupied with political questions regarding food related to the climate than sociable relations. The question of relation is connected to the question of how people may influence each other regarding waste reduction and climate emissions. The artist has created a base for dialogue where we can reassess our values and food behavior patterns. ${ }^{6}$ The

\footnotetext{
5 In the project Mind on Matters (2016), she also created meeting points.

${ }^{6}$ Concerning the want to make changes in society, we may ask whether this action rather verges on socially engaged art, which is concerned with social interactions and collaborative activity. The more ambitious projects engage with the public realm and the non-art community directly (Helguera, 2011). In this case, the artist collaborates with grocery stores and an education institution, an artist-run gallery, researchers and the general public. Interactions, workshops and collaborations with different
} 
Sissel Gunnerød: No Waste Cooking - An Exploration of Politics as

Redistribution of the Sensible

political aspect, which has been criticized as absent in relational aesthetics, is thus fully present in No Waste Cooking (Kroksnes, as cited in Bourriaud, 2007, pp. 174-189). ${ }^{7}$

\section{Politics as Inclusion of the Participant}

Since the sixties, an aesthetic turn toward the viewer has occurred in contemporary art (Ustvedt, 2002). This turn toward the viewer's presence and participation has impacted how contemporary art becomes political: the political becomes a process in the viewer, which the artist prepares for, generally through a request for involvement through action or reflection. An ambitious exceeding on behalf of art contributing to radical changes in the given society ought not to be taken for granted, however, as contemporary art rather deals with alterations through displacements or redistributions.

\section{Theoretical Perspective: Displacement and Dissensus}

In my approach to No Waste Cooking and its political aspects, I rely on the French philosopher Jacques Rancière's notion of politics as the distribution of the sensible, explained in Rancière's Le Partage du sensible: Esthétique et politique (2000), Malaise dans l'esthétique (2004) and Dissensus (2010). Politics and the arts have something in common: the distribution of the sensible. The sensible is something that is both partitioned and shared, with the partition of the sensible the dividing up of the world and the people (Rancière \& Corcoran, 2010, s. 36). Distribution, therefore, refers both to forms of participation and separation, inclusion as well as exclusion (Rancière, 2009b, p. 85; Rancière \& Corcoran, 2010, p. 36). Rancière gives an account of this by making a distinction between politics and police. ${ }^{8}$ Society is made

organizations or actors in society are among Hvistendahl's strategies in other art projects as well, but not the only ones.

${ }^{7}$ Relational aesthetics was given attention in Bishop (2004). She claims that the quality of the relationships in relational aesthetics are never examined or called into question. Bishop (2004) places the relations in relational aesthetics within an ideal of subjectivity as whole and of community as immanent togetherness and social harmony. Friction and antagonism, therefore, are missing (Bishop, 2004).

${ }^{8}$ Gabriel Rockhill has pointed out that '[...] the police is first and foremost an organization of 'bodies' based on a communal distribution of the sensible, i.e., a system of coordinates defining modes of being, doing, making, and communicating that establishes the borders between the visible and invisible, the audible and the inaudible, the sayable and the unsayable. This term should not be confused with la basse police or the low-level police force that the word commonly refers to both in both French and English. [...] The essence of the police, therefore, is not repression but rather a 
Sissel Gunnerød: No Waste Cooking - An Exploration of Politics as Redistribution of the Sensible

up of groups tied to specific modes of doing, to places where these occupations are practiced and to modes of being in accordance with these functions and places. However, there is no place for any void or supplement. While the police are characterized by the exclusion or absence of the void, politics consists of disturbing this arrangement with supplements. Rancière indicates that the essence of politics is dissensus, configuring a place in the community for what is not there and for what or who is not seen (Rancière \& Corcoran, 2010, p. 38). One world is placed in another, exceeding it (Rancière \& Corcoran, 2010, pp. 38-39). Indeed:

Politics revolves around what is seen and what can be said about it, around who has the ability to see and the talent to speak, around the properties of spaces and the possibilities of time. [...] Artistic practices are 'ways of doing and making' that intervene in the general distribution of ways of doing and making as well as in the relationships they maintain to modes of being and forms of visibility. (Rancière, 2009b, p. 13)

Art may reconfigure reality by redisposing the relationship between what is thought and what can be thought, what is seen and what can be said, what is done and what can be done. We might say that art redistributes what society has distributed. Therefore, art is a confrontation between what the world is and what it might be (Rancière, 2010, p. 44).

Moreover, in his elaboration of the relationship between art and politics, Rancière distinguishes between three regimes of art (Rancière, 2009b, pp. 20-30, 2010, pp. 28-29). The ethical regime refers to how images affect individuals' and communities' mode of being. The representative regime is a regime of visibility regarding the arts (genres), a mode of doing and making. Lastly, the aesthetic regime asserts art's singularity, distinguished as a specific sensible mode of being (Rancière, 2009b, pp. 20-30, 2010, pp. 28-29). This article focuses on the aesthetic regime of art.

\section{Radical or Modest Art?}

Rancière (2010) presents two conceptions of art today, developed from the assertion that the aesthetic utopia is dead and so, too, is the idea of artistic radicalism capable of transforming the conditions of collective existence (pp. 17-44). In the first conception, art is autonomous, its own reality. Art's radicalism is a power of

certain distribution of the sensible that precludes the emergence of politics" (Rockhill, as cited in Rancière, 2009b, p. 89). 
Sissel Gunnerød: No Waste Cooking - An Exploration of Politics as Redistribution of the Sensible

presence, tearing experience from ordinariness and exceeding the sensible (Rancière, 2010, p. 19). This position is favored by philosophers. The second conception, favored instead by artists and professionals in artistic institutions today, maintains distance to the first conception by proclaiming art's new modesty regarding art's singularity, self-sufficiency and capacity to transform the world (Rancière, 2010, p.21). Art "is a way of redisposing the objects and images that comprise the common world as it is already given, or of creating situations apt to modify our gazes and our attitudes with respect to this collective environment" (Rancière, 2010, p. 21). Microsituations give rise to new modes of confrontation and participation through displacement. The first conception makes a distinction between art and life, and the second eliminates art as a separate reality. Art becomes life, or at least varies slightly from ordinary life. Nevertheless, in both conceptions, art has a communitarian function by creating a specific space, a new form of dividing up the common world, redistributing it. The avant-garde does it by keeping distance to the market, and relational art does it by creating a common place with the spectator as actor. In these ways, art bears upon politics.

Politics is recognition of subjectivities capable of discussing the sensible distributed: "Politics consists in reconfiguring the distribution of the sensible which defines the common of a community, to introduce into it new subjects and objects, to render visible what had not been, and to make heard as speakers those who had been perceived as mere noisy animals" (Rancière, 2010, p. 25). Regarding art, the spectator is in fact acknowledged as an active participant in advance. According to Rancière, it is not art's assignment to make the spectator active. It is rather the thinking in terms of active and passive that causes the problem. He states:

Being a spectator is not some passive condition that we should transform into activity. It is our normal situation. [...] We do not have to transform spectators into actors, and ignoramuses into scholars. We have to recognize the knowledge at work in the ignoramus and the activity peculiar to the spectator. Every spectator is already an actor in her story; every actor, every man of action, is the spectator of the same story. (Rancière, 2009a, p. 17)

The quote above is about actors and spectators in the theater, though with transfer value to contemporary art. In the logic of emancipation, there is always a third thing alien to both the artist and the spectator, which they can refer to in common. It is not the transmission of the artist's knowledge or inspiration to the spectator: "it is the third thing that is owned by no one, whose meaning is owned by no one, but which 
Sissel Gunnerød: No Waste Cooking - An Exploration of Politics as

Redistribution of the Sensible

subsists between them, excluding any uniform transmission, any identity of cause and effect" (Rancière, 2009a, p. 15).

With notions of dissensus, displacement and redistribution of the sensible in which the viewer is recognized as an active participant, we are at the core of Rancière's theory on the relationship between art and politics. How do art practices participate in the partition of the sensible? The radical avant-garde practices politics by being selfsufficient and having nothing to do with it. Modest art practices politics by eliminating itself as art, becoming life. So, there is a tension between two opposed types of politics. We might think about it in terms of modernism and postmodernism, but Rancière resists this. He claims that if there is a question in contemporary art, "it will be grasped through an analysis of the metamorphosis of the political 'third,' the politics founded on the play of exchanges and displacements between the art world and that of non-art" (Rancière, 2010, p. 51). ${ }^{9}$ I am interested in this form of art, which slightly differs from life itself, but nevertheless contains (modest) political possibilities.

\section{Redistribution of Spaces}

Considering Hvistendahl's No Waste Cooking in light of Rancière's theory of politics in contemporary art, I am curious about this third thing between the artist and the spectator, which is food, and the politics in the exchanges and displacements between the art world and life. The project might be considered a form of micropolitics regarding the climate questions we face. Redistribution of spaces seems crucial. Hvistendahl creates a space for what is not there, a space for leftovers, sensations and reflections. In a culture where fresh food is a mantra, the artist serves leftovers beyond expiration date recommendations in grocery stores. A negative thought: "not fresh" is reformulated positively to "no waste cooking." The food we eat becomes art. Energy is generated in the bodies instead of waste and carbon emissions in the world (Hvistendahl, 2013). It revolves around a redistribution of material, mental and social spaces as well. Using perspectives from Rancière, we might say that strict modes of thinking and doing in society are supplemented with other ways of thinking and doing. If we consider one way of doing things as a space, another way of doing it is placed in the same space, exceeding it. Thus, No Waste Cooking is a contribution to heterogeneous spaces. To put it another way, the artistic

\footnotetext{
${ }^{9}$ One of these forms in contemporary art is the encounter or invitation. Rancière (2010) emphasizes relational art, which creates such situations.
} 
Sissel Gunnerød: No Waste Cooking - An Exploration of Politics as

Redistribution of the Sensible

practice of using leftovers intervenes in the general distribution of ways of doing and making things; wasting food.

\section{Consuming in Cities}

According to Bauman $(2000,2007)$, being a member of society is to enter the role of consuming. Miles and Miles (2004) claim that consumption is crucial to the experience of city life, representing the mental framework for constructing the contemporary city: "Human beings are no longer citizens of the city in which they live, but rather they are consumers in and consumers of that city" (p. 11). Living in a world where wishes are profound, the city is the main arena for stimulating these desires. Thus, the city legitimizes consumerism as a way of life. It provides a locale within which non-consumption is deemed a deviant act within its own geography. Regarding climate change, the authors ask whether there is more to city life than the opportunity to consume. I suggest that No Waste Cooking is a contribution to city life based on values other than consumption.

\section{An Urban Gleaner}

Another project on food in visual culture is Agnes Varda's film The Gleaners and I (2000), a documentary on various sorts of gleaning in France. ${ }^{10}$ To glean is to gather after the harvest. In accordance with the law, gleaning is possible when the harvest is over (Varda, 2000). In times past, gleaning was something women did, as shown in Jean-Francois Millet's painting Gleaners (1857) in the Muse' d'Orsay. Millet's Gleaners was depicted in all the dictionaries. Today, we find urban gleaners picking leftovers from the markets as in the fields of yesterday. ${ }^{11}$ One example in Varda's film is potatoes. For supermarkets, potatoes have to be a special size; green, outsized or damaged potatoes are dumped. Because great amounts of potatoes and other vegetables are dumped, the practice of gleaning has reappeared. As shown in the film, many vulnerable people are sustained by gleaning. One of the persons in the film is well-educated, but sells magazines as his livelihood. He gets fruits, vegetables and sometimes cheese from the market and collects bread and sandwiches from

\footnotetext{
10 The original title is Les Glaneurs et la Glaneuse.

11 The filmmaker points out that each person gleans on his own now, whereas in paintings people were in groups, rarely alone. Does it have something to do with dignity? In times past, it was more common to glean among the rural working class: they were allowed to go through the fields at sunset to pick up the ears of corn missed by the harvesters. In present times, it might be connected with shame to perform similar gleaning in towns, going through leftovers from markets. Could it be one of the reasons why each gleans on his own now?
} 
Sissel Gunnerød: No Waste Cooking - An Exploration of Politics as

Redistribution of the Sensible

another location. He lives in a shelter in which $50 \%$ of the residents are illiterate; in the evenings, he has been teaching them to read and write. This has been going on for many years. Meeting that person was what impressed the filmmaker most, as it showed that gleaning is not only for disadvantaged people. Another person in the film says that salvaging is a matter of ethics for him. He has a job; thus, gleaning is not of necessity. The filmmaker is a gleaner as well, of images, impressions and information with the camera through city areas and rural fields.

Connecting The Gleaners and I to No Waste Cooking, Hvistendahl is an urban gleaner who intervenes between grocery stores and consumers in the city. She is like the chef in the film who says that nothing should be wasted. However, because of her collaboration with grocery stores, Hvistendahl's gleaning is invisible. She is not gleaning in the sense of going through the trash bins outside the grocery stores, as some of the informants in the film do. Nevertheless, by using food that otherwise would have been thrown away, Hvistendahl makes herself a gleaner. Moreover, by making tasty meals, she shows citizens that food after its final date recommendation is fully edible. Thus, preparing and eating leftovers, and gleaning as well, might become a model for imitation.

\section{Art Becomes Life}

At the same time as No Waste Cooking, by chance there was an exhibition called Hungry Planet. What the World Eats (2013/2014) at the Nobel Peace Center in Oslo. The exhibition, produced in collaboration with two artists, photographer Peter Menzel and writer Faith D'Alusio (2005), showed what families around the world eat in one week. Not surprisingly, some have far too much food and others far too little. The viewers were invited into the kitchens of families around the world to see how the food we eat affects the global environment and climate.

Enthusiastic about the art project in Stockholm, I contacted the Nobel Peace Center by email, informing them of the project No Waste Cooking: Maybe the art action was of current interest during the exhibition? I promptly got an answer in the form of an invitation to an event called Restetorsdag (Leftover Thursday) the next day. Curious about this coincidence, I went to see the exhibition and join the gathering. The event was a collaboration of the Peace Center, the food organization ForMat and private actors and took place in the exhibition area. ${ }^{12}$ It consisted of information and

12 ForMat is the Norwegian business sector's organization for preventing food waste. 
Sissel Gunnerød: No Waste Cooking - An Exploration of Politics as Redistribution of the Sensible

entertainment from different experts, including a nutritionist who had recently published a book on leftovers-based food. A huge assembly of vegetables and fruits after their "date of expiry" from groceries filled the scene to the brim. Afterward, the visitors were invited to gather the fruits and vegetables to bring home for free. Finally, we were given a meal consisting of a Ribollita soup as the main dish and Norwegian waffles as dessert, all made of leftovers from Norwegian groceries like Rema 1000 and Meny. The meal had been prepared by a dietitian, who was also the author of the cookbook Restekjærlighet (2013). ${ }^{13}$ Indeed, the soup recipe was from this book.

What strikes me is the huge concurrence in the art project No Waste Cooking in Stockholm and Leftover Thursday at the Peace Center in Oslo. Rancière (2010) has aptly pointed out that contemporary art eliminates art as a separate reality (p. 36). This concurrence between an art action and an arrangement in society may underline his point: Art differs slightly from life, art becomes life. However, as a participant of Leftover Thursday, I must admit that it was not possible to avoid the feeling that one of the lectures was a marketing of the dietitian's recently published cookbook, which was offered for sale in the museum shop at a nice price that evening and advertised as a suitable Christmas present. Even though I am critical of the consuming aspect of the event at the Nobel Peace Center due to the cookbook's marketing, it might be that a cookbook makes the implementation of the social practice easier in everyday life than an art project without any sequels. In fact, Eliasson's SOE Kitchen has resulted in a beautiful cookbook with over 100 recipes for the home cook from the studio kitchen. The boundaries between the art world and life are blurred in this way, but the question remains: Is there more to city life than the opportunity to consume (Miles \& Miles, 2004)?

Is viewing art an alternative to consuming or part of it? The art action No Waste Cooking performed in the artist-run gallery in Stockholm did not appear as consumption in the same way, perhaps because there was neither art nor anything else to buy, not even a catalogue. On the contrary, No Waste Cooking is dependent on what it criticizes. If art practices in general "are ways of doing and making that intervene in the general distribution of ways of doing and making" (Rancière, 2009, p. 13), and if this specific art action is a redistribution of the sensible, it is heterogeneous, consisting of the redundant food it fights against. One world is placed in another, exceeding it. Thus, claiming that art in general is not part of consumerism

${ }^{13}$ Restekjærlighet (Leftover love) is a Norwegian pun playing on the words charity and leftovers. 
Sissel Gunnerød: No Waste Cooking - An Exploration of Politics as

Redistribution of the Sensible

is simplifying it. Viewing art might be part of consuming, too. However, I perceive another, agenda in the art action: creating sensations and reflections. Using Rancière's term, it is a way of redistributing a common practice among Nordic citizens: In Scandinavian countries, expiration dates are the main reason why people throw food away (NRK.TV, 2015). A reflection about final date recommendations is that the label "best before" does not mean that the food is inedible. ${ }^{14}$ Instead of discarding food, the viewer is challenged to use her senses and consider what to make out of the food in her own home. It makes sensible experience preparing and eating such food. Thus, the aesthetic is thought of together with the political and not degraded as in socially engaged art. ${ }^{15}$

According to Rancière, the political is rather implied in the impact of art than the artists' agenda or endeavors. He questions the assumption that artists' work can have precise, intended effects. ${ }^{16}$ Regarding the political agenda in No Waste Cooking, we might think of it with Rancière's notion of police. In this case, the explicit "want to make a change" attitude in the project induces the notion of police because it defines modes of being and doing. Thinking with Rancière, another objection is that the artwork seems to maintain thinking in terms of active and passive participants, which he neglects. He has an unreserved belief in the participant, although he or she might be unreflected. Thus, a question arises: Does the wish to influence preclude politics in terms of (re)distributing the sensible?

Not necessarily. Even though No Waste Cooking has a clear and conscious agenda activating people for better choices regarding food waste, it is displayed as negotiations. An example might be ethical considerations arising regarding leftovers. There is an ambivalence and dilemma in the fact that meat very often is a leftover that otherwise will be thrown away and the fact that meat is a baddie in terms of emissions. Thus, what seems to solve a problem in the first place creates a new problem in the second. A rebound effect might occur. We know from research that both meat and dairy products ought to be reduced to mitigate greenhouse gas

\footnotetext{
14 Stuart (2009) explains that "the best-before date and use-by date have different purposes under law; the first is merely a guarantee of quality; the second is a guide to food safety" (p. 62).

15 Bishop (2006) claims that a major problem in the discussion around socially engaged art is its paradoxical relationship to the aesthetic. It also includes criticism indicating that socially engaged art focuses on the exemplary ethical gesture and rejects aesthetic potency.

16 In an interview, Rancière expresses skepticism toward "art that tries too hard to be provocative and relentlessly mobilizes all our senses. Art should also allow us to be absorbed in our thoughts, to distance ourselves, to have a moment of rest" (Wójcik, 2015).
} 
Sissel Gunnerød: No Waste Cooking - An Exploration of Politics as Redistribution of the Sensible

emissions (Garnett, 2011, p. 31). Cows in pastures especially produce methane when belching. ${ }^{17}$ Hvistendahl solves this dilemma by prioritizing vegetarian food with elements of meat and fish. She does not want to serve hot dogs to visitors; when she receives that sort of food, she gives them away so people can make their own dinner at home. In her social art practice, she is a flexitarian, eating meat occasionally. In this case, the work of art might be a model for imitation, but what is more important is that it is capable of posing ethical questions and presenting contemporary dilemmas. In this sense, the art action has a didactic function, displaying ethical questions and possible ways to deal with them without unambiguous answers. The participant may make another conclusion: the artwork becomes an opportunity to think through these issues with art. The art action, then, is an invitation to relate these issues to our own lives.

A question emerges: What can art do versus non-art? What can No Waste Cooking do versus Restetorsdag at Hungry Planet. What the World Eats? When art and life are blurred, the contexts might be decisive. Restetorsdag was a one-time event at the Nobel Peace Center while No Waste Cooking is a recurrent action in multiple cities. I suggest with caution that No Waste Cooking mainly reaches the art audience, while the Nobel Peace Center might have a more general public. However, Hvistendahl has also cooked for students and staff at Chalmeyers University of Technology in Gothenburg, so this suggestion might be oversimplified. In both cases, situations are made that look similar, with like goals and societal effects. What remains is that No Waste Cooking has a double function that Restetorsdag lacks: it operates within both the realms of society and the art world. It is considered and evaluated as art in the art world. ${ }^{18}$

Food after its expiration date has become the fulcrum in No Waste Cooking, the third thing in which the artist, the visitors, the author and the readers are invited to connect, verify or reject, elaborate and develop for further discussion and

\footnotetext{
17 Regarding the forecast of a food shortage in the future, a shorter food chain is smarter: for example, producing grain for human beings instead of feeding it to animals raised for meat. However, grain production is only possible in flat areas. In Norway, for instance, there is a tradition of meat production because a considerable part of the landscape is mountainous. As such, a discussion is going on between self-suffiency regarding food against the fact that agriculture accounts for a major part of greenhouse gas emissions.

18 Helguera (2011) states that the art world evaluates art projects not just for what they have accomplished, but also as symbolic actions-as art (pp. 5-8, 36).
} 
Sissel Gunnerød: No Waste Cooking - An Exploration of Politics as

Redistribution of the Sensible

proliferation. However, regarding the political, impact matters. Regarding the impact, I just have my own experiences of imitating the artist, yet with possibilities for proliferation and ramifications through influence. Without any comments from visitors, I will abstain from creating absolute answers. We do not know if No Waste Cooking functions with lasting repercussions. The effects this art action causes are open, with possibilities for discussions, actions or nothing. Nevertheless, I suggest that a microsituation has given rise to new modes of participation in consumer society through displacement and dissensus. We might speak of dissensus because gleaning leftover food is a rather rare occupation in a rich country. Hvistendahl has created a common place with the spectator as an actor not merely in the present moment in the gallery, but hopefully with lasting repercussions. For larger changes in society, changes at the system level are needed: for example sustainable farming, manufacturing, distribution and retailing. Still, on the individual level, the art action's visitors are invited to eat more responsibly and waste less food. If the effect is rather modest than radical, its importance lies in allowing proliferation and ramification to happen.

\section{Conclusion}

In conclusion, we might say that No Waste Cooking may contribute to politics as a redistribution of a mental and social space regarding food-with possibilities for participation, discussion and transformation. However, a presupposition is that the receiver accepts the invitation. As an urban gleaner, the artist intervenes between grocery stores and consumers, preventing food wasting and creating a space for leftovers, sensations and reflections. However, ethical considerations about the food available are still necessary. In this sense, the art action has a didactic function, displaying ethical questions and possible ways to deal with them without straightforward answers. Related to similar projects in the field of visual culture, the political aspect in No Waste Cooking in terms of redistribution of the sensible seems possible, albeit in a modest alteration: Art becomes life.

\section{Author Presentation}

Sissel Gunnerød is Associate Professor in Art and Design History at OsloMet - Oslo Metropolitan University, Faculty of Technology, Art and Design, Department of Art, Design and Drama. Research interests include aesthetics, contemporary art and sustainability. 
Sissel Gunnerød: No Waste Cooking - An Exploration of Politics as

Redistribution of the Sensible

\section{References}

Bauman, Z. (2000). Globalization - The human consequences. Cambridge: Polity Press.

Bauman, Z. (2007). Consuming life. Cambridge: Polity Press.

Bell, S., Chketiani, N., Donlin, P., Fraenkel-Eidse, J., Gleitsmann, D., Lilleby Kildal, C.

\& Oliveira, M. (Eds.). (2014). Food rights and food fights. Tvergastein. Interdisciplinary Journal of the Environment.

https://issuu.com/tvergasteinjournal/docs/tvergastein web

Bishop, C. (2004). Antagonism and relational aesthetics. October Magazine, Ltd. and Massachusetts Institute of Technology, October(110), pp. 51-79.

https://doi.org/10.1162/0162287042379810

Bishop, C. (2006). The social turn: Collaboration and its discontent. Artforum, February, pp. 179-185.

Bourriaud, N. (2007). Relasjonell estetikk (B. Scheel-Christensen, Trans.). Oslo: Pax Artes.

Dessein, J., Soini, K., Fairclough, G., \& Horlings, L. (Eds.) (2015). Culture in, for and as sustainable development. Conclusions from the COST action IS1007 investigating cultural sustainability. University of Jyväskilä, Finland.

Eliasson, O., Studio Eliasson \& Waters, A. (2016). Studio Olafur Eliasson: The Kitchen. London: Phaidon Press Ltd.

EU's waste framework directive. (2008). Retrieved from http://ec.europa.eu/environment/waste/framework/

Garnett, T. (2011). Where are the best opportunities for reducing greenhouse gas emission in the food system? Food Policy, 36, pp. 23-32.

https://doi.org/10.1016/j.foodpol.2010.10.010

Gordon Matta Clark: Food. (1972). Retrieved from https://www.youtube.com/watch?v=WhB8riHoueA\&t=0s\&list=PLcK3JzU PbKu OzMVcTkmnuW7LQOVktfWY\&index=7

Heilmann, S., \& Døscher, K. (2011). Restekjærlighet - Den store restematkokeboka. Oslo: Dinamo.

Helguera, P. (2011). Education for socially engaged art. A materials and techniques handbook. New York, NY: Jorge Pinto Books.

Menzel, P. \& D' Alusio, F. (2005). Hungry planet: What the world eats. Berkeley, California: Ten Speed Press.

Hvistendahl, A. (2013). Project description. No Waste Cooking. Retrieved from http://nowastecooking.blogspot.com/ 
Sissel Gunnerød: No Waste Cooking - An Exploration of Politics as

Redistribution of the Sensible

Kroksnes, A. (2007). Etterord In N. Bourriaud (Ed.), Relasjonell estetikk. (B. ScheelChristensen, Trans.) (pp. 169-189). Oslo: Pax Artes.

Miles, S., \& Miles, M. (2004). Consuming cities. New York, NY: Palgrave Macmillan. https://doi.org/10.1007/978-0-230-80264-3

Nicholson, W. (2014). Food and global warming, a starting point for food sustainability?

Tvergastein - Interdisciplinary Journal of the Environment, 5(2), pp. 7-11. https://issuu.com/tvergasteinjournal/docs/tvergastein web

Rancière, J. (2009a). The emancipated spectator (G. Eliott, Trans.). London \& New York: Verso.

Rancière, J. (2009b). The politics of aesthetics - The distribution of the sensible. (G. Rockhill, Trans.). London \& New York: Continuum.

Rancière, J. (2010). Aesthetics and its discontents (S. Corcoran, Trans.). Cambridge \& Malden: Polity Press.

Rancière, J., \& Corcoran, S. (Eds.). (2010). Dissensus (S. Corcoran, Trans.). London \& New York: Continuum.

Rirkrit Tiravanija. (2012, February, 3). MoMA: MoMA PS1 Blog. Retrieved from https://www.moma.org/explore/inside out/2012/02/03/rirkrit-tiravanija-cookingup-an-art-experience/

Stuart, T. (2009). Waste - Uncovering the global food scandal. London: Penguin Books.

NRK.TV. (2015, Mars, 27). Skavlan [Television broadcast]. NRK1. Retrieved from https://tv.nrk.no/serie/skavlan/2015/KMTE50001215/avspiller

Ustvedt, Ø. (2002). Passenger - The viewer as participant. Oslo: Astrup Fearnley Museum of Modern Art.

Varda, A. (2000). The gleaners and I [Documentary]. United States: Zeitgeist Films.

Wójcik, A. (2015). The politics of art: An interview with Jacques Ranciére. Versobooks. Retrieved from https://www.versobooks.com/blogs/2320-the-politics-of-art-an-interview-withjacques-ranciere 